\title{
Nemzetlko̊zi múzeumok honlapjainak áttekintése, kïlönös tekintettel a szellemi rekreáció két aspektusára
}

\section{Website Evaluation of International Museums in Two Main Aspects of Mental Recreation}

\section{O̊SSZEFOGLATH:S:}

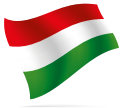

A szellemi rekreáció területéről, azaz a „nemmozgásos" szabadidőtöltés formái közül a cikk a múzeumokra fókuszál. A tanulmány célja ezen intézmények honlapjainak általános vizsgálata és áttekintése a szellemi rekreáció tekintetében. A múzeumok programjai úgy nyújtanak kulturális élményt, hogy személyes jelenlétet igényelnek a helyszínen. A tanulmány azt vizsgálja, hogy ezt hogyan támogatják a honlapok, valamint kitér arra is, hogy a múzeumok nyújtanak-e olyan szolgáltatást honlapjaikon keresztül, amelyek nem igényelnek személyes jelenlétet az intézményekben. Vagyis otthoni vagy iskolai környezetben is „megszerezhetik-e” az érdeklődők a múzeumok által biztosított kulturális élményt és ismeretet a virtuális tér segítségével? Kulcsszavak magyarul: Múzeumi weboldal, weboldalelemzés, virtuális tárlatlátogatás

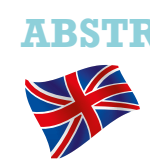

This paper focuses on museums as they are part of mental recreation also known as "non-motion" activity of the leisure time. The purpose of the study is to examine and review the websites of these institutions in terms of mental recreation. This cultural leisure program provides a cultural experience that typically needs a personal presence on the spot. The article discusses whether museums provide special information or other services through their websites that do not require personal presence in the institutions, supporting the cultural experience in a home or school environment through the virtual space. Keywords: websites of museums, website evaluation, virtual tour

\section{BEVEZETES}

„A nemzeti kultúra legfontosabb őrzőhelyei a közgyűjtemények, a közgyűjteményekben felhalmozott tudás a nemzeti identitástudat és a modern ismeretek legfontosabb alapja" (Nemzetgazdasági Minisztérium, 2012, 162. o.). A kulturális intézmények a kultúraközvetítés intézményrendszerének ré-

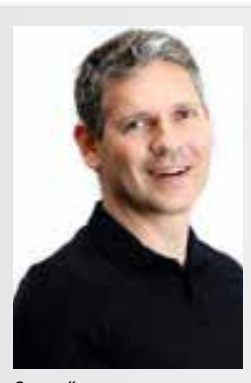

Szerző:

Beosztás: Tulajdonos

Munkahelye: ALEhopp Kft.

1037 Budapest, Sereg u. 3/B

E-mail címe: info@ALEhopp.hu

Kutatási területei / Érdeklódési köre:Weboldalelemzés,

adatbányászat, müvészetek

Fotó: Nagy Lajos
Losonczi György

Levelezési címe: szei és ezáltal a „művelődésnek és a szellemi élet"-nek is szerves részei (eduline. hu, 2009, 1. o.). A „közgyújtemények könyvtár, múzeum, levéltár" (eduline.hu, 2009, 8. o.) „az információk legszélesebb körű hozzáférést biztosító intézményei" (Bereczky et al., 2004) az országokban. Ez oknál fogva minden kommunikációs felületen (pl. honlapon) elérhetővé kellene tenni az információ minél szélesebb elérését, és nem csak az adott ország hivatalos nyelvén, hanem az Európai Unió hivatalos nyelvein is. A tanulmány megvizsgálja a múzeumok honlapjait abból a szempontból, hogy nyújtanak-e olyan szolgáltatást honlapjaikon keresztül, amelyek nem igényelnek személyes jelenlétet az intézményekben, vagyis virtuálisan is megvalósul-e a kultúraközvetítés?

\section{IMÓDSZEREIK}

A szerző több éve foglalkozik a közgyűjteményi honlapok vizsgálatával, amelyek eredményei hazai és nemzetközi konferenciákon kerültek publikálásra. A weboldalelemzés módszertani alapját a szerző által létrehozott CW-Index keretrendszer adja (Losonczi, 2014), amely több területen került adaptálásra, így a közgyűjteményi intézményekre, múzeumokra is (Losonczi, 2017). A vizsgálat elsősorban az EU28 nemzeti múzeumok honlapjaira terjed ki.

\section{EREDIVIENYE}

$A z$ eredmények bemutatása két részben kerül ismertetésre. Az első a nemzeti múzeumok honlapjai általános megvalósításának eredményeit mutatja be, míg a második rész a „virtuális kultúraközvetítéssel” kapcsolatos eredményekre fókuszál.

Az általános vizsgálat a honlapok alapvető nyelvi kommunikációját is érintette. A 2014-es eredményekhez képest (Losonczi, 2016) jelentős változás nem történt a honlapok nyelvi támogatását illetően. Továbbra is az országok a saját hivatalos nyelvüket használják, megerősítve azt a 2014-es tapasztalatot, hogy az EU28 intézményei nem törekednek az EU28 nyelvek teljes körű támogatására. Az EU28 közgyújteményi intézmények (múzeumok, könyvtárak, levéltárak) honlapjain az angol nyelv (83\%-ban) dominált a hivatalos nyelv mellett (Losonczi, 2016), múzeumok esetén a 28 tagállamból 26 (+ Nagy-Britannia) támogatja az angol nyelvet 2017-ben. Megállapítható, hogy az Európai Unió által képviselt „multi nyelvü” (multilingual) intézmény ideál, azaz egy közösség több eltérő kultúra/nyelv elv (European Commission, 2006) a gyakorlatban nem valósul meg. Az EU28 nemzeti múzeumok honlapjai között számos területen mérhető a különbség. A honlapon megcélzott célcsoportok elérésében (azaz megfelelö céltartalmak biztosítása) a V4 országok jól teljesítettek a „média” és „oktatás” célcsoportok terén, de jelentős a lemaradás az „üzleti támogatók, partnerek" esetén.

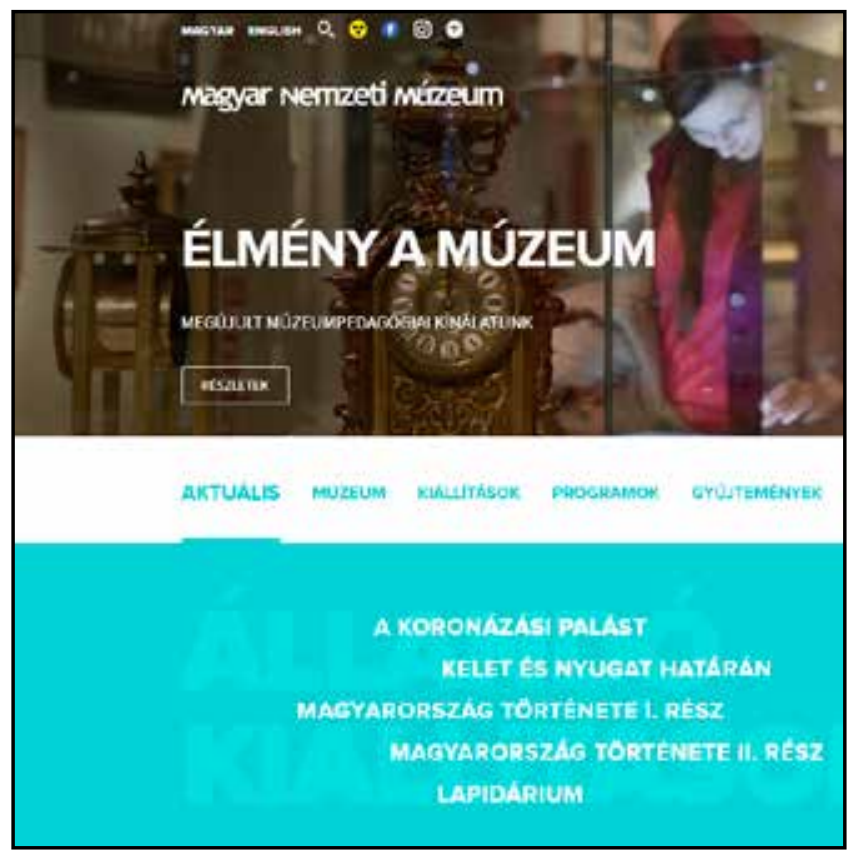

Magyar Nemzeti Múzeum honlap részlete / The Website of the Hungarian National Musem Forrása: http://www.mnm.hu 
A honlap branding kapcsán a tapasztalat az, hogy a V4-ek nem használják ki pl. a misszió/vízió kommunikálását vagy a társadalmi felelősségvállalás (Corporate Social Responsibility, rövidítve CSR) lehetőségeket. Figyelemre méltó, hogy a V4 nemzeti múzeumjai egyes social média területen alulteljesítenek, kevésbé használják az online videót (pl. Youtube), online képmegosztást (pl. Instagram) vagy a microblog esetén pl. a Twitter-t. Az EU28 tekintetében a honlapok navigációs támogatottságában nem volt jelentős különbség, a V4 honlapok többsége mobil eszközökre is optimalizált.

Az eredmények a „virtuális kultúraközvetítéssel” kapcsolatos szolgáltatások terén vegyes. Az EU15 nemzeti múzeum honlapjain már online megvehető a belépőjegy, továbbá részletesebb információt nyújtanak, mint az EU15-ön kívüli intézmények. Az EU28-ból 13 esetben a honlapon keresztül kínáltak tudományos kutatók számára információs oldalt. A Magyar Nemzeti Múzeum kutatóknak készült oldalán három fő lehetőséget kínál: kutatás a múzeum teljes digitális állományában, az 1916-os és 1956-os fényképtárban, továbbá az Ariadne régészeti adatbázisban is lehet keresni (59.581 lelőhely, 1.158.779 fájl, 5.957.700 keresőkifejezés) (MNM. hu, 2017a). Mindegyik esetben kutatási engedély szükséges.

A múzeumok honlapjain az EU28-ból Luxemburg, Olaszország, Ausztria és Bulgária esetében nem volt található oktatással kapcsolatos weboldaltartalom vagy múzeumpedagógia oldal. A Magyar Nemzeti Múzeum „Múzeumpedagógia" menüpont alatt számos tartalmat kínál, mint például múzeumi órákat, drámapedagógiát és múzeumpedagógiai kiadványokat (MNM.hu, 2017b). A Louvre több célcsoportnak is nyújt ilyen jellegű szolgáltatást a tanárok és diákok mellett, mint például a családoknak, 30 éveseknek (Louvre, 2017a).

Online tárlat területén az EU28-ból 13 rendelkezik online adatbázissal, erre jó példa a British Museum adatbázisa, amely 4 millió kereshető objektummal rendelkezik (Britishmuseum.org, 2017a).

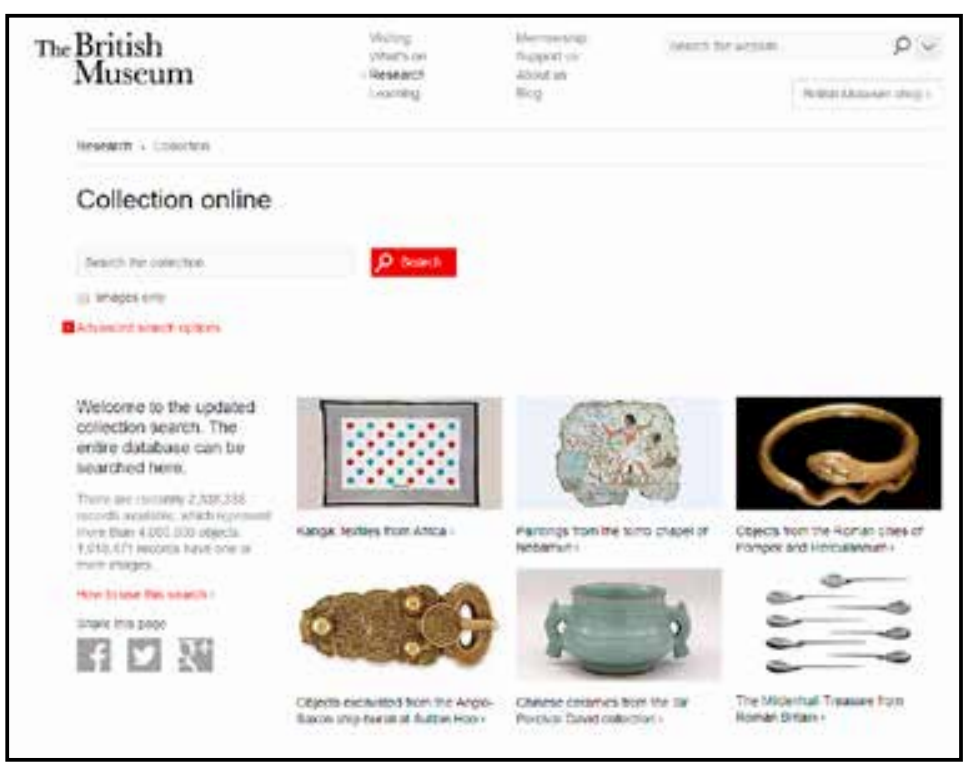

A British Museum online keresóje / The Search Collection of the British Museum Forrása: http://www.britishmuseum.org/research/collection_online/search.aspx

A Louvre esetén kilenc online katalógusban lehet keresni a múzeumban található mútárgyak között. Az egyszerű keresések mellett további lehetőségeket is kínál, mint például épületszárny vagy teremszintű műtárgy keresést (Louvre, 2017b). A Svéd Nemzeti Múzeum a kereső mellett „online tour"-t is ajánl több témakörben, pl. barokk, Greta Garbo (Nationalmuseum.se, 2017), amely valójában egy tematikus lejátszási lista alapján mutatja be a releváns adatbázis képeit. Az online katalógussal és keresővel rendelkező intézmények az eredményes keresés esetén a mútárgy képével, méretével, elnevezésével és a múalkotó nevével tér vissza a találatban. A Magyar Nemzeti Múzeum nem rendelkezik ilyen jellegű szolgáltatással. A Google által kezdeményezett Art Projekt-en belül közel 60 múzeum megtalálható, köztük számos nemzeti múzeum is. Több, mint 45 ezer objektumot tárol magas felbontású digitális anyagként, és a Streetview technológia támogatásával „járható be” az intézmények helységei és tekinthetők meg a mútárgyai (Google, 2017).

A virtuális workshop, virtuális osztály szolgáltatások az USA-ban már nem új keletűek (penn.museum, 2017), de Európában még nem elterjedtek, ilyen jellegű szolgáltatásokat nem talált a vizsgálat. Virtuális tárlatvezetést két intézmény alkalmaz a honlapján. A Louvre 360 fokos online tárlatvezetésével a nevesebb kiállítások tekinthetők meg, a múemlékekre kattintva további kép és információ jelenik meg (Louvre, 2017c).

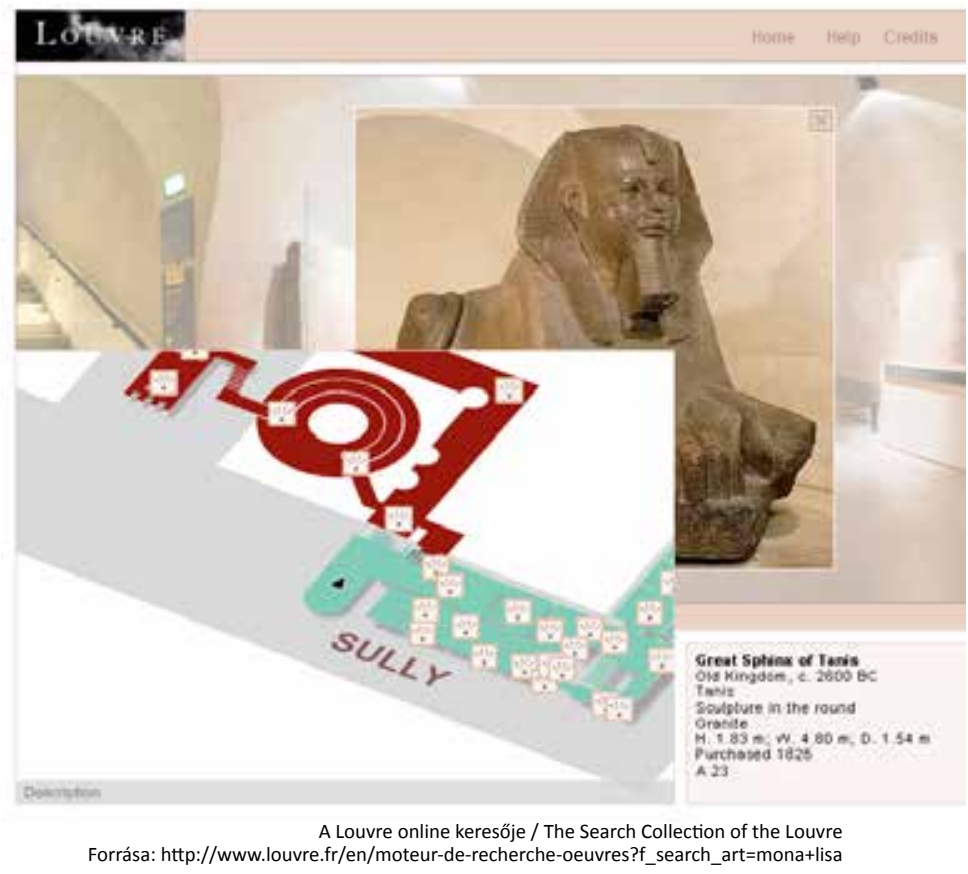

A British Museum a Google-lal közösen a Google Streetview szolgáltatással (Britishmuseum.org, 2017b) hasonló digitális élményt nyújt a felhasználóknak.

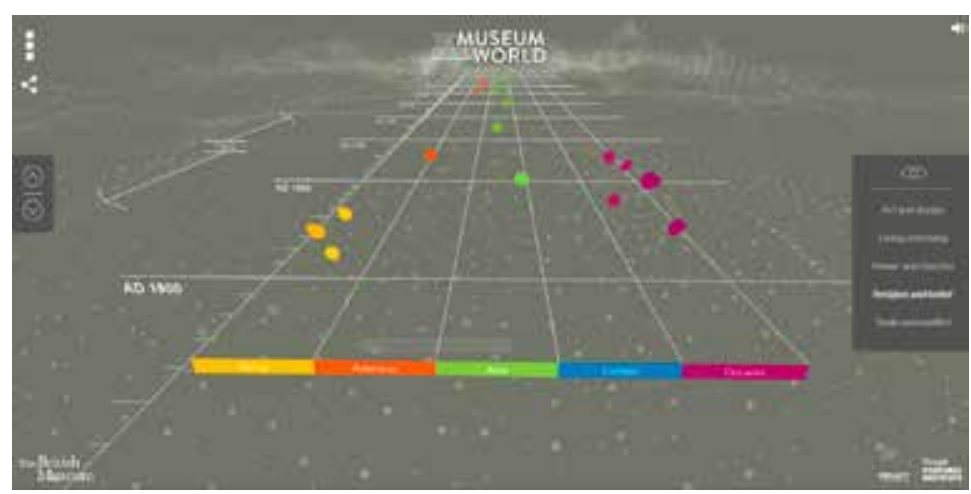

(Folytatás a következó oldalon) 


\section{KO̊VETKEZTETESET}

Az EU28 nemzeti múzeumai a hivatalos nyelvet használják, és továbbra se törekednek az EU28 nyelvek teljes körü támogatására. Néhány eset kivételével mindegyik oldalon megtalálhatóak a múzeumpedagógiával kapcsolatos szolgáltatások.

Több múzeum online katalógussal is rendelkezik, amelyek mindenki számára elérhetőek korlátozás nélkül. Néhány intézmény esetében megtalálható a virtuális tárlatvezetés szolgáltatás, ezzel szemben a virtuális workshop-ot egy intézmény sem kínálja, alkalmazza.

Összességében megállapítható, hogy a nemzeti múzeumok kultúraközvetítő szerepe továbbra is „offline” jellegú, azaz személyes jelenlétet igényel, a virtuális élményt nyújtó szolgáltatások még nem terjedtek el kellőképpen.

\section{IRODALOIVIEGYZET}

Google (2017): Google Arts \& Culture | Collections. From: https:// www.google.com/culturalinstitute/beta/partner?hl=en

Bereczky, L. - Geczényi, L - Gyürei, V. - Monok I. - Fejős, Z Kovács, T. (2004): A közgyűjtemények a nemzeti kulturális örökség digitalizálásában. From: http://magyar-irodalom.elte.hu/biop/ barbar/cikkek/20040601.htm

Britishmuseum.org (2017a): The British Museum - Collection online. From: http://www.britishmuseum.org/research/collection_ online/search.aspx

Britishmuseum.org (2017b): The British Museum with Google. From: http://www.britishmuseum.org/with_google.aspx

eduline.hu (2009): A kultúraközvetítés intézményrendszere. From: http://eduline.hu/segedanyagtalalatok/letolt/4589 1-8. o.

European Commission (2006): Special Eurobarometer 286 Europeans and their Languages. From: ec.europa.eu/public_ opinion/archives/ebs/ebs_243_en.pdf

Losonczi Gy. (2014): Magyar felsőoktatási intézmények honlapjainak versenyképesség vizsgálata nemzetközi viszonylatban. E-CONOM 3. 139-156. o. DOI: 10.17836/EC.2014.1.139.

Losonczi Gy. (2016): Nemzeti közgyűjteményi honlapok nyelvi támogatásának elemzése. STUDIA MUNDI - ECONOMICA 3:(1) 6283. o.

Losonczi Gy. (2017): Website Evaluation of the National Museums. Vydavatelstvo Univerzity Mateja Bela - Belianum. 29-228.

Louvre.fr (2017a): Louvre. From: http://www.louvre.fr

Louvre.fr (2017b): Louvre - Search the Collection. From: http:// www.louvre.fr/en/moteur-de-recherche-oeuvres?tab=3\#tabs

Louvre.fr (2017c): Louvre - Online Tours. From: http://www. louvre.fr/en/visites-en-ligne\#tabs

MNM.hu (2017a): Magyar Nemzeti Múzeum - Kutatóknak. From: https://mnm.hu/hu/kutatoknak

MNM.hu (2017b): Magyar Nemzeti Múzeum -

Múzeumpedagógia. From: https://mnm.hu/hu/muzeum/muzeumiinformaciok/muzeumpedagogia

Nationalmuseum.se (2017): Nationalmuseum - Explore the Collections. From: http://emp-web-22.zetcom.ch/eMuseumPlus?se rvice $=$ Externallnterface $\&$ module $=$ exhibition $\&$ moduleFunction $=$ resu It\&filterName=filter.tours.all\&lang=en

Nemzetgazdasági Minisztérium (2012): Nemzeti fejlesztés 2020 Az Országos Fejlesztési Koncepció és az Országos Területfejlesztési Koncepció társadalmi egyeztetési változata. http://kecskemet.hu/ foepitesz/nf2020_oftk.pdf 16. o.

penn.museum (2017): Penn Museum - Virtual Programs. From: https://www. penn.museum/teachers-and-students/in-yourclassroom/virtual-programs

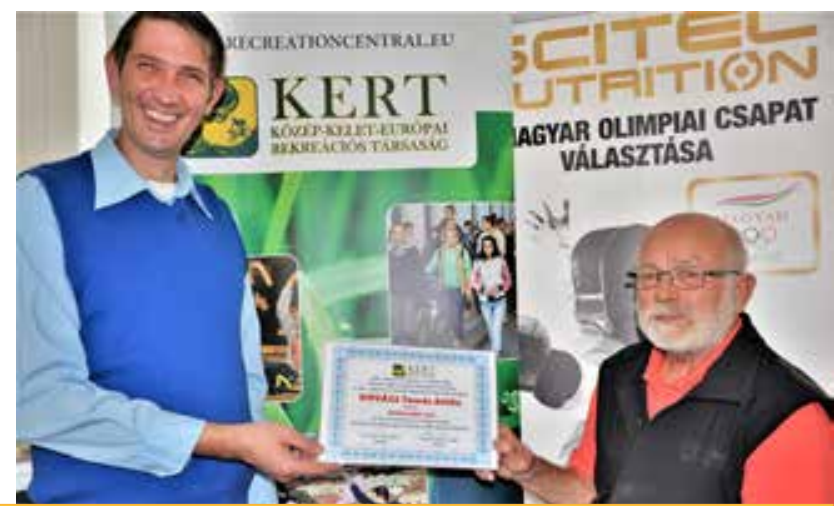

\section{Budapest}

Kovács Tamás Attila számos hazai publikáció szerzője a rekreáció, sport, edzéstan, rekreációs szakmai oktatás témáiban. Többek között az ő nevéhez kapcsolódik, hogy a rekreáció a magyar felsőoktatásba önálló területként be tudott integrálódni, első́ként az ELTE TFK testnevelésrekreáció tanári szakpáros képzés formájában. A sísport tekintetében a hazai és nemzetközi válogatottak mellett is hosszú évekig edzősködött, de ennek rekreációs vonulatát és oktatását is elősegítette munkásságával. A gyakorlati ismeretek kiegészítéseként az elméleti megközelítéseket és a háttér vizsgálatát is fontosnak tartja, ezzel is hozzájárul a tudományos munka fejlődéséhez is.

Jelenleg az ELTE-n Kondicionálás tantárgyat oktat, mely szívügye a koordinációs képességek fejlesztése mellett.

Aktív tag az OKJ szakmai vizsgaelnökök regiszterében a sportedző és -oktató különböző szakágai, a rekreációs, fitness és a sportszervező menedzser képzések területén.

A KERT 2017. május 19-i közgyülésén a tagok egyhangúan megszavazták a Tanár Úr tiszteletbeli tagságát, amelyhez kapcsolódóan díszoklevelet adott át az elnökség tagja, Magyar Márton titkár az ELTE Bogdánffy úti sporttelepén.

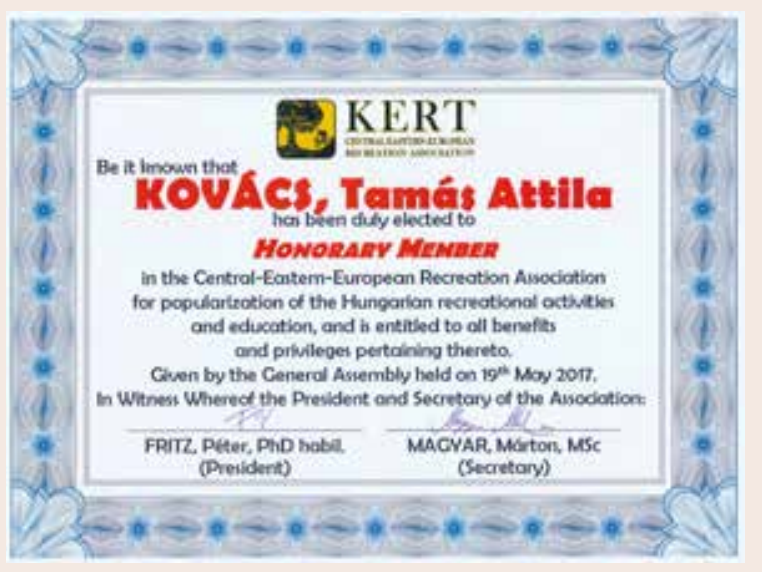

